\title{
CORPORA POLÍTICA: A POTÊNCIA CRIATIVA E CONTESTATIVA DA ESCRITA DE ANA CRISTINA CESAR E ANGÉLICA FREITAS
}

\section{CORPORA POLITICA: THE CREATIVE AND CONTESTATIVE POWER OF ANA CRISTINA CESAR'S AND ANGÉLICA FREITAS'S WRITING}

\author{
Daniel Almeida Machado' \\ [https://orcid.org/0000-0002-9415-622X \\ Angela Maria Guida ${ }^{2}$ \\ [https://orcid.org/0000-0002-8948-646X] \\ DOI: 10.30612/raido.v14i35.11865
}

\begin{abstract}
RESUMO: O silenciamento de vozes femininas na literatura revela certa dificuldade de reconhecer a possibilidade de que a mulher tensione e pense em temas para além do cenário doméstico. Neste sentido, o presente artigo propóe um diálogo entre duas poetisas, Ana Cristina Cesar (na coletânea Poética, de 2013) e Angélica Freitas (em Útero é do tamanho de um punho, de 2017), vislumbrando na poética de ambas a inserçáo de temários que dialoguem com um lado político de ser mulher e a inclusáo do olhar feminino como discurso capaz de perscrutar posicionamentos contrários às imposiçôes sociais sobre o papel da mulher na sociedade. Alicerçando-nos precipuamente pelos estudos de poesia (HOLLANDA, 2001a; 2001b), a crítica feminista (DUARTE, 2019; SCHMIDT (2019), os estudos de gênero (BUTLER, 2019) e, acima de tudo, o diálogo entre poemas de ambas as escritoras, desejamos demonstrar a potencialidade de uma dicçâo poética oriunda do feminino.
\end{abstract}

Palavras-Chave: Literatura brasileira; Mulheres na literatura; Poesia; Literatura e gênero.

ABSTRACT: The silencing of female voices in the literature reveals some difficulty in recognizing the possibility that women may tense and think about themes beyond the domestic sphere. In this sense, the present article proposes a dialogue between two poets, Ana Cristina Cesar (in the collection Poetic, 2013) and Angélica Freitas (in A uterus is the size of a fist, 2017), glimpsing in the poetics of both the insertion of themes that dialogue with a political side of being a woman and the inclusion of the female gaze as a discourse capable of searching positions contrary to social impositions on the role of women in society. Basically based on poetry studies (HOLLANDA, 2001a; 2001b), feminist criticism (DUARTE, 2019; SCHMIDT, 2019), gender studies (BUTLER, 2019) and, above all, the dialogue between poems of both writers, we wish to demonstrate the potential of a poetic diction from the feminine.

Keywords: Brazilian literature; Women in literature; Poetry; Literature and gender.

1 Mestrando do Programa de Pós-graduaçăo em Estudos de Linguagens/FAALC (UFMS). Bolsista CAPES. E-mail: danimachx22@gmail.com

2 Doutora em Ciência da Literatura/Poética (UFJR). Professora do Programa de Pós-Graduaçâo em Estudos de Linguagens/FAALC (UFMS).E-mail: angelaguida.ufms@gmail.com. 


\section{CONSIDERAÇÕES INICIAIS}

As mulheres e as crianças sâo as primeiras que desistem de afundar navios. (CESAR, 2013, p. 87)

porque uma mulher boa / é uma mulher limpa [...] (FREITAS, 2017, p. 11)

Em 21 de janeiro de 1931, a escritora britânica Virginia Woolf lê um texto para a Sociedade Nacional de Auxílio às mulheres, uma organizaçăo da Inglaterra preocupada com a emancipaçăo feminina e a posiçấo da mulher no mercado de trabalho. Intitulada de Profissóes para mulheres, a conferência é inspiradora e extremamente atual, na medida em que Virginia Woolf compartilha sua trajetória enquanto romancista e os percalços envolvidos em sua formaçâo. A autora comenta que teve um momento de epifania quando iria resenhar o romance de um escritor famoso e um fantasma recorrente, que a autora nomeia de o "anjo do lar", ${ }^{3}$ sussurrou-lhe: "Querida, você é uma moça. Está escrevendo sobre um livro que foi escrito por um homem. Seja afável; seja meiga; lisonjeie; engane; use todas as artes e manhas de nosso sexo [...] E principalmente seja pura."' (WOOLF, 2013, p. 12). Sob pena de que o anjo arrancasse o coraçăo de sua escrita, a soluçấo encontrada por Virginia foi a de matá-lo, em um gesto que é creditado por ela própria como um dos mais corajosos de sua carreira literária.

Analogamente, queremos pensar nas escritoras brasileiras que, tăo valentes quanto Virginia Woolf, fizeram de sua escrita um ato de recusa às submissóes, valendo-se da literatura enquanto possibilidade de ressignificar aquilo que é colocado como proveniente do espaço feminino. É o caso de duas poetisas: Ana Cristina Cesar, nas décadas de 70 e 80, em pleno contexto ditatorial brasileiro e cuja presença de uma voz feminina solidificava-se aos poucos na literatura e em outras instâncias; e de Angélica Freitas, no final da primeira década e início da segunda década do século XXI, surgindo na onda de uma nova explosâo do movimento feminista e da reivindicaçâo de diversos feminismos/femininos.

No raiar de uma geraçăo chamada de mimeógrafo, de escritores e escritoras que produziam seus poemas de forma independente, uma "poesia marginal" como resposta às vozes autoritárias e de censura da ditadura, a carioca Ana Cristina Cesar escreveu Cenas de abril (1979), Correspondência completa (1979) e Luvas de pelica (1980). Em 1982, um ano antes de seu suicídio, publica pela editora Brasiliense A teus pés, uma coletânea de seus escritos anteriores e uma seçăo de prosa/poesia com o mesmo título do livro. Uma literatura sem precedentes, cuja interiorizaçâo da intimidade, sua maior arma, fez com que a escritora estabelecesse o que Heloisa Buarque de Hollanda chamou de "o prazer do pacto secreto com seu possível interlocutor. A isso ela chamava de "pathos feminino". Disso, ela fez seguramente a melhor e a mais original literatura produzida dos anos 1970" (HOLLANDA, 2013a, p. 451).

O "efeito Ana C." influenciou uma legiăo de leitoras/escritoras ávidas e com uma identificaçăo por aquela literatura fora do eixo. É o caso da poetisa gaúcha Angélica Freitas que em 2007 surge no cenário da literatura brasileira contemporânea com Rilke Shake, um apanhado de seus escritos até entăo e em 2012 com o premiado Um

3 "O anjo do lar" é o título de um poema de Coventry Patmore (1823-1896) que idealiza um casamento feliz para a mulher que fosse submissa e afeita aos afazeres domésticos. 
útero é do tamanho de um punho, ambas produçóes que ecoam uma forma de expressăo desgarrada do verso milimetricamente posicionado, tal qual a poesia de Ana Cristina Cesar. Em entrevista, Angélica descreve como se deu o contato com aquela que viria a ser uma de suas maiores inspiraçóes literárias:

Eu năo tinha livro de poesia em casa, meus pais năo liam poesia. Um amigo meu, o Andrei, me emprestou Fernando Pessoa e Ana Cristina Cesar. O pai dele era professor de letras da UFPEL e tinha milhares de livros em casa. O Andrei viu que eu gostava de escrever e teve essa brilhante ideia. Eu tinha 15 anos quando ele me emprestou Ana Cristina Cesar, e foi muito importante. Li e me causou um estranhamento, de ler e năo entender o que estava lendo, mas achava aquilo absolutamente fascinante. E daí fiz a pergunta: "mas dá pra escrever assim entâo?". (FREITAS, 2012, s/p)

O estranhamento de Angélica Freitas com o corpo poético de Ana Cristina Cesar, um efeito de choque e novidade recorrente aos leitores e leitoras de ontem e de hoje, foi muito bem traduzido em um poema que Freitas escreveu em 2016, ano em que a grande homenageada da Festa Literária de Paraty (Flip) foi Ana Cristina Cesar.

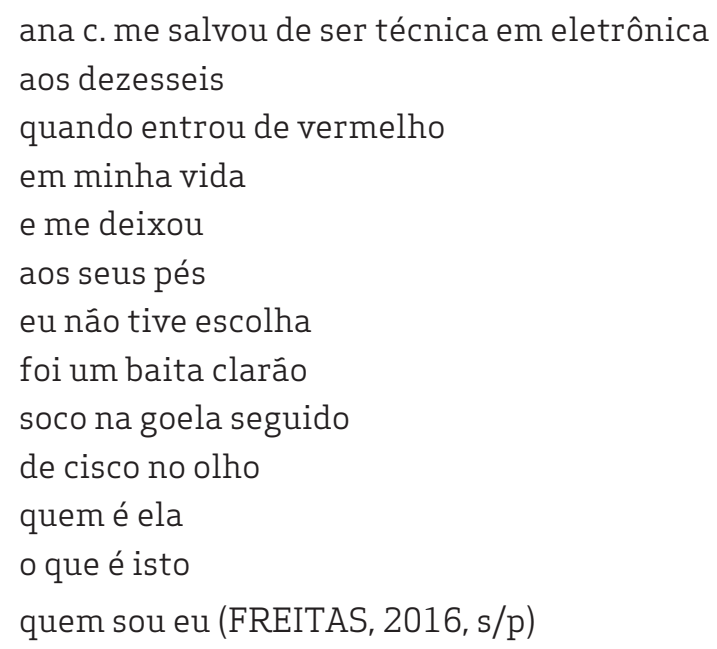

O poema é uma pura homenagem ao próprio trabalho de Ana Cristina Cesar, com referências diretas a sua produçâo poética, como nos versos "e me deixou / aos seus pés", uma alusăo à obra A teus pés, ou "soco na goela seguido / de cisco no olho", passagem contida no epílogo de Luvas de pelica. Singular e singela, é na sequência final que Angélica melhor descreve o contato avassalador com esse outro, "quem é ela / o que é isto / quem sou eu", traduzindo de maneira sincera o desnorteamento de uma poesia que instaura um "pacto secreto", como dito por Heloisa Buarque de Hollanda (2013). Ao poder dessa literatura, talvez possamos clamar como Freitas: "eu năo tive escolha".

Desse modo, propomos um diálogo entre alguns poemas de Ana Cristina Cesar e de Angélica Freitas, sobretudo à luz de um olhar que, para além da comparaçâo entre as duas, perceba as maneiras como ambas inserem-se na literatura como formas de contestaçáo e questionamento às atribuiçóes comuns da escrita feminina, de uma certa docilidade e contençăo das palavras. Ana Cristina Cesar e Angélica Freitas săo leituras exímias para compreender a insurgência de um novo ideário feminino/feminista. Uma literatura que reposiciona a mulher do contexto doméstico para um lugar, de fato, de livre arbítrio. 


\title{
2 UMA ESCRITORA TEM O DIREITO TUDO DIZER
}

Como aponta Julia Klein em seu artigo "Na poesia" (2018), um apanhado da safra literária de mulheres de 2010 para cá e parte integrante do livro Explosâo feminista (2018), a poesia de autoria feminina do século XXI é marcada por uma autonomia de vozes - lésbicas, trans, negras, entre outras - em que a vontade de dizer é maior do que se conter. Uma poesia marcada pela exterioridade do sentimento, a necessidade da denúncia, o compartilhamento das experiências. Klein (2018) considera que há uma relaçấo direta dessa poesia com o lançamento de Ana Cristina Cesar no horizonte da literatura brasileira, na qual a autora afirma:

\begin{abstract}
Já é quase senso comum dizer que a obra de Ana C. foi o solo da poética das principais poetas contemporâneas do país: Alice Sant'Anna, Marilia Garcia, Ana Martins Marques, Bruna Beber, Angélica Freitas e Annita Costa Malufe. Essas poetas me parecer sem as herdeiras mais imediatas do "efeito Ana C." e trabalham - ou săo lidas - nesse diapasăo. (KLEIN, 2018, p. 105).
\end{abstract}

Se a poesia de Ana Cristina Cesar nos idos de 1980 representou (e ainda representa) a efervescência necessária para que uma nova dicçăo poética surgisse, é por meio de uma de suas herdeiras diretas, Angélica Freitas, que a poesia feita por mulheres ganha um novo referencial na contemporaneidade e a confirmaçăo de que uma escritora mulher tudo pode dizer: “É nesse terreno já meio conquistado que as novíssimas poetas do feminismo surgem. Sua maior referência é Angélica Freitas, com o livro Um útero é do tamanho de um punho (lançado em 2012 pela Cosac Naify e reeditado em 2017 pela Companhia das Letras" (KLEIN, 2018, p. 106). Tanto Ana Cristina quanto Angélica tornam-se parâmetros para uma nova identificaçăo de poesia e escritura, estabelecendo um grau de parentesco literário e de renovaçōes de vozes femininas na literatura, tanto para o passado quanto para o presente. Tomemos como exemplo Ana Cristina Cesar e a primeira parte de seus "arpejos", de Cenas de abril

\footnotetext{
Acordei com coceira no hímen. No bidê com espelhinho examinei o local. Năo surpreendi indícios de moléstia. Meus olhos leigos na certa năo percebem que um rouge a mais tem um significado a mais. Passei pomada branca até que a pele (rugosa e murcha) ficasse brilhante. Com essa murcharam igualmente meus projetos de ir de bicicleta à ponta do arpoador. 0 selim poderia reavivar a irritaçăo. Em vez decidi me dedicar à leitura. (CESAR, 2013, p. 70).
}

Em Profissōes para mulheres (1931), mesmo após declarar que havia matado “o anjo do lar", Virginia Woolf confessava que outra barreira precisava ser transposta, "falar a verdade sobre minhas experiências do corpo, creio que năo resolvi. Duvido que alguma mulher já tenha resolvido" (WOOLF, 2013, p. 17). A confissâo da escritora denota um dos problemas de gênero no qual a experiência feminina foi edificada na sociedade: uma subordinaçấo à pureza, à castidade, aos ditames de um devir-mulher que criou noçóes como a maternidade compulsória, o silenciamento das vontades e o casamento enquanto oportunidade legítima de "emancipaçăo". A "mulher enquanto substância" permanente" (BUTLER, 2019, p. 55) e que já nasce marcada para ser uma, sem a possibilidade de tornar-se (BEAUVOIR, 1980, p. 9). Nesse constructo, cria-se a impossibilidade de que a mulher conheça (e fale) de seu próprio corpo. A mistificaçăo desnecessária, nas palavras da autora: 
Sem dar à menor atençăo à verdade fisiológica, diz-se que o óvulo, imóvel, fica à espera do exercício tumultuoso e valente de espermatozóides para ser fecundado. Ninguém fala da longa e perigosa viagem solitária percorrida pelo óvulo através de túneis obscuros. Esse livro que aborda uma viagem pelo lado do confinamento é uma contribuiçăo à biologia do segredo e à maldade desse tom. (CESAR apud HOLLANDA, 2013b, p. 443)

Assim sendo, foge aos princípios naturalizados e à ilusăo histórica do sexo feminino o eu lírico de "arpejos". Começa com a declaraçăo/constataçâo de que acordou "com coceira no hímen". A exposiçâo despudorada do próprio corpo e a exterioridade de uma experiência interior, até entăo nâo permitidas para o discurso feminino, seguem-se com as incertezas do acontecido "meus olhos leigos na certa nâo percebem que um rouge a mais tem um significado a mais". Abre-se o leque para diversas leituras, como é notório dos poemas de Ana Cristina Cesar de acordo com Viviana Bosi: "a impossibilidade de se apossar de seus versos" (BOSI, 2013, p. 425). Pode-se pensar que o eu lírico feminino teve uma noite de sexo no dia anterior, a causa da irritaçăo de seu hímen, ou que está ironizando divertidamente a relaçâo que a película vaginal possui com a ideia de virgindade (a mistificaçăo de que uma mulher virgem é uma mulher que possui o hímen intacto), ideia contraposta com "nâo surpreendi indícios de moléstia". Brincase com o imaginário sexual, com imagens como o arpoador e o selim, que podem ser associados respectivamente com os órgáos sexuais masculino e feminino e a situaçáo de "ir de bicicleta à ponta do arpoador". Por fim, após passar "pomada até que a pele branca (rugosa e murcha) ficasse brilhante", o sujeito termina sua confissâo decidindo por dedicar-se à leitura, desfazendo-se dos planos anteriores.

A maneira com que Ana Cristina Cesar lida com o corpo feminino e o cotidiano, em uma retórica da intimidade, evoca a naturalidade de que a mulher possa falar de seu corpo, seus desejos, que possa se observar sem pudor "no bidê com o espelhinho examinei o local", sem que se haja uma condenaçâo por tais atos. Sâo as características de uma poesis libertadora, especialmente no contexto de sua produçáo, os reprimidos e autoritários anos de ditadura brasileira, em que o corpo mais uma vez foi sacralizado como uma instância improfanável. O sexo, corpo e desejo tornam-se matéria para uma linguagem corriqueira e banal, e a dificuldade de externalizá-los cede espaço para abertura de suas vontades, especialmente como reinvindicaçăo das mulheres, tal qual observa-se em "16 de junho":

Posso ouvir minha voz feminina: estou cansada de ser homem. Ângela nega pelos olhos: a woman left lonely. Finda-se o dia. Vinde meninos, vinde a Jesus. A bíblia e o hinário no colinho. Meia branca. Órgáo que o papai tocava. A bênçấo final amém. Reviradíssima no beliche de solteiro. Mamáe veio cheirar e percebeu tudo. Mâe vê dentro dos olhos do coraçáo mas eu estou cansada de ser homem. [...] Eu sou o caminho a verdade e a vida. Lâmpada para meus pés é a tua palavra. E luz para o meu caminho. Posso ouvir a voz. Amém, mamáe. (CESAR, 2013, p.32)

Talvez um dos poemas mais sinceros (e revisitados) de Ana Cristina Cesar, pois há um questionamento direto em relaçấo à condiçâo de ser mulher no mundo com o eu lírico feminino que clama desde o início "estou cansada de ser homem". Năo é contra o homem ou ser homem no sentido ontológico que o eu lírico se revolta, mas com a situaçấo de introjetar-se no mundo pela via da masculinidade, uma das únicas maneiras de impor-se e fazer-se ouvida. Năo é de estranhar, portanto, que escritoras como as irmăs 
Brontë assinassem suas obras com pseudônimos masculinos ou Jane Austen publicasse anonimamente. "Por muito tempo na história, "anônimo" era mulher" dizia Virginia Woolf. Ou, driblando o anonimato mais ainda sim silenciando sua própria existência, faziam se passar por homens.

O eu lírico, no entanto, encontra-se sozinha, "a woman left lonely" e o poema é entrecortado por imagens religiosas como "a bênçăo final amém" e "eu sou o caminho a verdade e a vida". Há a presença da mâe, que parece igualmente presa à compulsoriedade das açōes atribuídas ao sexo feminino "posso ouvir sua voz. Amém, mamáe" e que também săo perpetuadas por determinados discursos religiosos. Mesmo que a figura materna tenha boas intençôes, o eu lírico está cansado: "Máe vê dentro dos olhos do coraçăo mas estou cansada de ser homem". Cansada de ser homem, ou cansada da ideia que o homem tem sobre a mulher. Uma mulher que, ainda no século XXI, deva ser "bela, recatada e do lar". 5

No caso de "arpejos" e "16 de junho", como bem observa Heloisa Buarque de Hollanda no importantíssimo mapeamento poético 26 poetas hoje lançado em 1976 e que serviu como uma bússola para o conhecimento da poesia brasileira feita naquela época, e da qual constava Ana Cristina Cesar, a geraçấo de 60 e 70 demonstrava uma nova experiência de leitura e de literatura. Irrompem o "flash cotidiano e o corriqueiro", a "transcriçăo de sentimentos comuns", a "poetizaçăo do relato" (HOLLANDA, 2001a, p.11), bem como de uma "linguagem informal, à primeira vista fácil, leve e engraçada" (HOLLANDA, 2001a, p. 10) e que singularizava ironicamente aquele momento político de anos de chumbo sem que se criasse uma "poesia social de tipo missionário e esquemático" (HOLLANDA, 2001a, p.12), inclusive se levarmos em conta os câes de guarda do governo sempre alertas para qualquer "subversăo" explícita. Em suma, sob a alcunha de uma geraçâo marginal da poesia brasileira, era uma literatura que se opunha aos modelos classicizantes, ainda que fossem comumente referenciados, como é o exemplo do índice onomástico deixado por Ana Cristina Cesar no final de seu A teus pés, de 1982. 6 Heloisa Buarque de Hollanda questionava se todos esses atributos poderiam caracterizar um movimento literário insurgente na literatura brasileira ou se năo passavam de um mero modismo, o que nâo se confirmou nas geraçōes futuras e em outros momentos da poesia da própria Ana Cristina Cesar, como é o caso do último poema escolhido de Ana C. e que faz parte da antologia 50 poemas de revolta (2017):

4 "Uma mulher abandonada" (traduçâo nossa). "A woman left lonely" (1971) é ainda uma cançâo de Janis Joplin, que nos versos iniciais canta: "A woman left lonely will soon grow tired of waiting,/ She'll do crazy things, yeah, on lonely occasions" (Uma mulher abandonada logo ficará cansada de esperar / Ela vai fazer coisas loucas, em ocasiôes solitárias, traduçâo nossa).

5 Esses foram os adjetivos utilizados pela Revista Veja para qualificar a ex-primeira-dama Marcela Temer, em uma matéria cujo título foi "Marcela Temer: bela, recatada e do lar". (Cf.: <https://veja.abril.com.br/ brasil/marcela-temer-bela-recatada-e-do-lar/>. Acesso em: 24 mar. 2020.)

6 O índice continha os seguintes escritores e escritoras: Francisco Alvim, Eudoro Augusto, Manuel Bandeira, Elizabeth Bishop, Helô Buarque, Angela Carneiro, Emily Dickinson, Grazyna Drabik, Carlos Drummond, Armando Freitas, Billie Holiday, James Joyce, Mary Kleinman, Katherine Mansfield, Cecília Meireles, Angela Melim, Murilo Mendes, Katia Muricy, Octavio Paz, Vera Pedrosa, Jean Rhys, Gertrude Stein e Walt Whitman. 


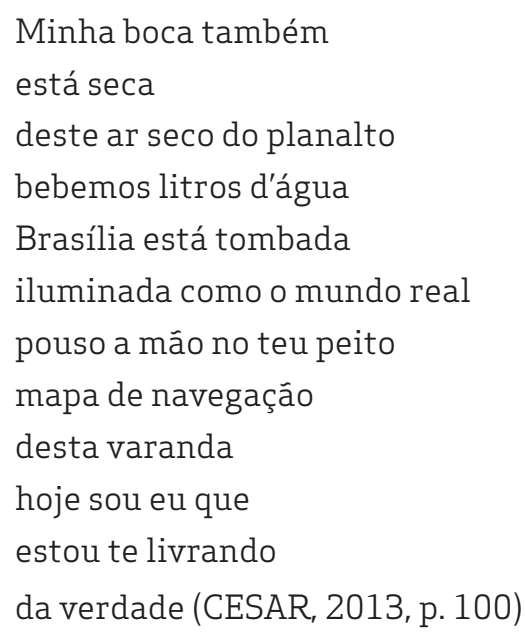

Como é característico da poética de Ana Cristina Cesar, o poema suscita figuras ambíguas. A "boca seca" e o "ar seco" tanto podem referir-se à baixa umidade do ar ou, se devidamente localizados, "do planalto", fazendo parte de um certo incômodo para determinada situaçăo do país, haja vista que o planalto é o epicentro político brasileiro. 0 eu lírico prossegue com "Brasília está tombada/", novamente em direçăo à dubiedade: a cidade pode estar "tombada" enquanto patrimônio histórico ou em pleno declínio, em uma sutil ironia para o momento político do país, em que os militares haviam tomado o poder. A cidade está "/iluminada como o mundo real/", pulsa e grita, tal qual o alerta que de que o rei está nu, ao que parece difícil, para o eu lírico, desconsiderar o estado atual de sua naçăo.

No segundo momento, novamente um gesto ambivalente do eu lírico, "/pouso a măo no teu peito/", que tanto indica no imaginário coletivo um sinal de respeito, como quando colocamos a máo no peito durante o proclamaçấo do hino ou em outros eventos de caráter protocolar - como a cerimônia de um funeral, passagem da vida para a morte e, metaforicamente, podemos pensar na própria morte da democracia . Entretanto, num gesto de alívio, o eu lírico encerra com a declaraçáo de que "/hoje sou eu que / estou te livrando / da verdade/", que faz lembrar uma das falas da protagonista de Hiroshima mon amour (1959) para seu amante: "É preciso evitar pensar nas dificuldades que o mundo nos apresenta algumas vezes. Senăo, ele seria irrespirável". $\mathrm{Ou}$, pode ser um livramento das tentativas de "verdades oficiais", aquelas em que se tenta apagar da história os momentos sombrios, fazendo com que nossa curta memória queira reavivar, décadas depois, a mesma cruel e injusta ilusâo de justiça de outrora. Ana Cristina Cesar articula uma poesia aparentemente descomprometida, de efeito satírico e irônico, cujas leituras confirmam o impacto para a futura geraçăo de poetas e, especialmente, de escritoras mulheres.

Essa repercussāo posterior é novamente analisada por Heloisa Buarque de Hollanda, quando, passadas duas décadas, em 1998 publica Esses poetas, na qual percebe certas mudanças de tom literário com os poetas e poetisas que escrevem a partir da década de 90. Ainda há uma linguagem informal e, acima de tudo, "uma confluência de linguagens, um emaranhado de formas e temáticas" (HOLLANDA, 2001b, p. 11). No entanto, se os/as escritores da geraçăo anterior eram colocados como "marginais", o perfil dessa nova leva é de um "profissional culto, que preza a crítica, tem formaçăo superior e que atua, com desenvoltura, no jornalismo e no ensaio acadêmico" (HOLLANDA, 2001b, pp. 
10-11) e, de especial importância para o âmbito de nosso trabalho: "a poesia articula-se, em várias realizaçóes e performances, com as artes plásticas, com a fotografia, com a música, com o trabalho corporal" (HOLLANDA, 2001b, p. 14, grifo nosso). Também a "angústia da influência" năo é um problema, como aponta a intelectual, "se torna usual, nesta geraçăo de autores, a mençăo a suas tribos ou famílias poéticas" (HOLLANDA, 2001b, p. 17). Por fim, se a presença feminina foi "revelada com força total na década passada" (HOLLANDA, 2001b, p. 11) é a partir dessa nova leva literária que ela se faz de modo definitivo, tal qual o exemplo de Angélica Freitas, poetisa que congrega traços comuns entre ambas as geraçôes.

Gaúcha e com formaçăo em jornalismo pela Universidade do Rio Grande do Sul (UFRGS), é na literatura que Angélica Freitas encontra um local de experimentaçáo e a passagem de leitora voraz à escritora brilhante. Em seu primeiro livro, Rilke Shake (2007), a autora brinca com a tradiçâo literária, associando desde o título uma mistura improvável do cânone literário, já que "Rilke" faz alusăo ao poeta alemăo Rainer Maria Rilke. Outrossim, săo citados/as no livro escritores/as como Ezra Pound, Gertrude Stein e Elizabeth Bishop, essa última presente no despojado e ácido "liz \& lota":

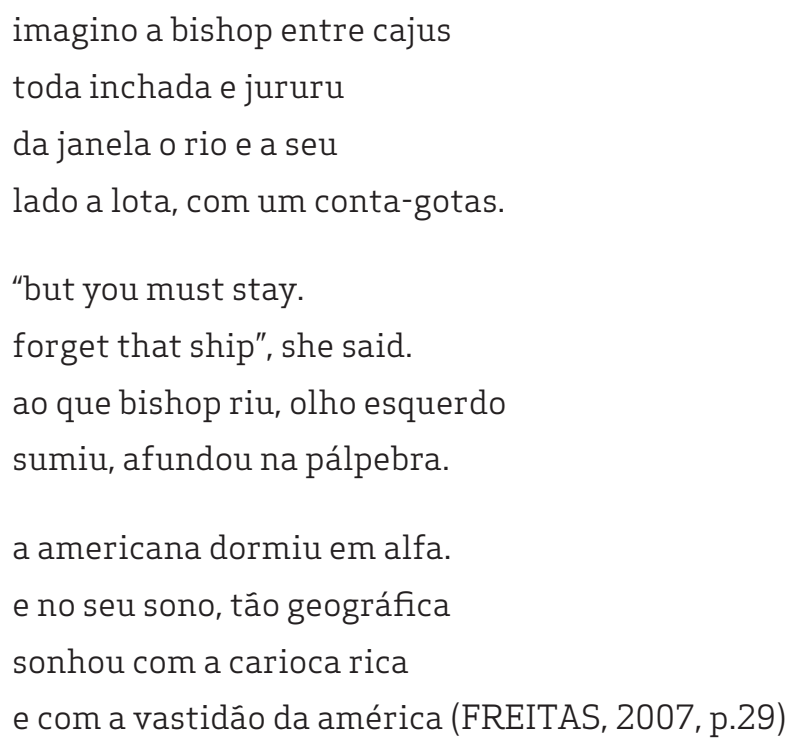

O poema já inicia com uma referência literária: Elizabeth Bishop (1911-1979) foi uma exímia poetisa norte-americana, ganhadora do Prêmio Pulitzer de Poesia por North \& South em 1956 e que morou no Brasil nas décadas de 50 e 60. Misturam-se no poema elementos ficcionais "/imagino a bishop entre cajus/" com situaçôes reais (Bishop era alérgica a cajus), envolvidos por um toque de humor "/toda inchada e jururu/" e ironia "/lado a lota, com um conta-gotas/" (Bishop era depressiva e tinha problemas com alcoolismo). Ficcionaliza-se, ainda, o enlace amoroso lésbico entre Bishop e a arquiteta brasileira Maria Carlota Costallat de Macedo de Moraes7, conhecida por Lota, desde o título do poema "liz \& lota", que sugere um relacionamento e também um vínculo comercial entre as duas, pressuposto pelo sinal \& comumente utilizado

7 No plano da ficçâo, a relaçăo entre as duas pode ser observada no filme Flores raras (2013), do diretor brasileiro Bruno Barreto. 
em relaçôes comerciais e cuja possibilidade de leitura é acionada pelo verso "/sonhou com a carioca rica/". Quase que espiando pelo buraco de uma fechadura, o leitor pode imaginar cenas cotidianas de ambas e até fantasiar uma dramática súplica de Lota a Elizabeth, feita em língua inglesa, / "but you must stay / forget that ship, she said./8", para que a escritora năo retornasse aos Estados Unidos. O romance de duas mulheres enquanto matéria de poesia.

As características citadas de 26 poetas hoje (1976) e Esses poetas (1990) sâo percebidas, em maior ou em menor tom, quer seja da geraçăo de 90 ou das geraçôes anteriores, na escrita do primeiro de livro de Angélica Freitas e no exemplo do poema "Liz \& Lota", assim como na poesia de suas irmás literárias: Alice Sant'Anna, Ana Martins Marques, Annita Costa Malufe, Alice Sant'Anna, Marília Garcia, Matilde Campilho, entre outras, oriundas de uma estética moderna. No caso específico de Angélica, outros rumos foram tomados que se diferenciam em certa medida dos adotados até entăo em Rilke Shake. É o caso da publicaçăo de seu segundo livro de poemas Um útero é do tamanho de um punho em 2012 pela Cosac Naify e reeditado em 2017 pela Companhia das Letras (ediçấo utilizada por nós). Uma "literatura empenhada" (CANDIDO, 2013), na medida em que a escrita literária de Angélica se compromete com uma problemática social específica e a construçáo de uma obra em que sobressaia "em termos esteticamente valiosos os pontos de vista humanitários e políticos" (CANDIDO, 2013, p. 184).

Nesse sentido, o âmbito político-social de Útero é do tamanho de um punho é percebido já em seu título, que nâo trata de uma mera exposiçăo/comparaçăo de partes do corpo feminino, mas, dialogicamente, faz com que o/a leitor/a leia o signo literário de Freitas compreendendo a intrínseca relaçâo entre o significante, do plano da expressâo, com o significado, do plano do conteúdo. Se bem lembramos os pressupostos da linguística moderna (SAUSSURE, 2012), a própria alteraçăo no significante promoveria uma alteraçăo no significado, em outras palavras, nada na língua é por acaso. Nâo obstante, a segunda ediçăo do livro, utilizada por nós, traz uma instigante capa:

8 /“Mas você deve ficar/, /esqueça aquele navio, ela disse”. (Traduçăo nossa) 
Figura 1 - Capa de Um útero é do tamanho de um punho (2017), de Angélica Freitas.

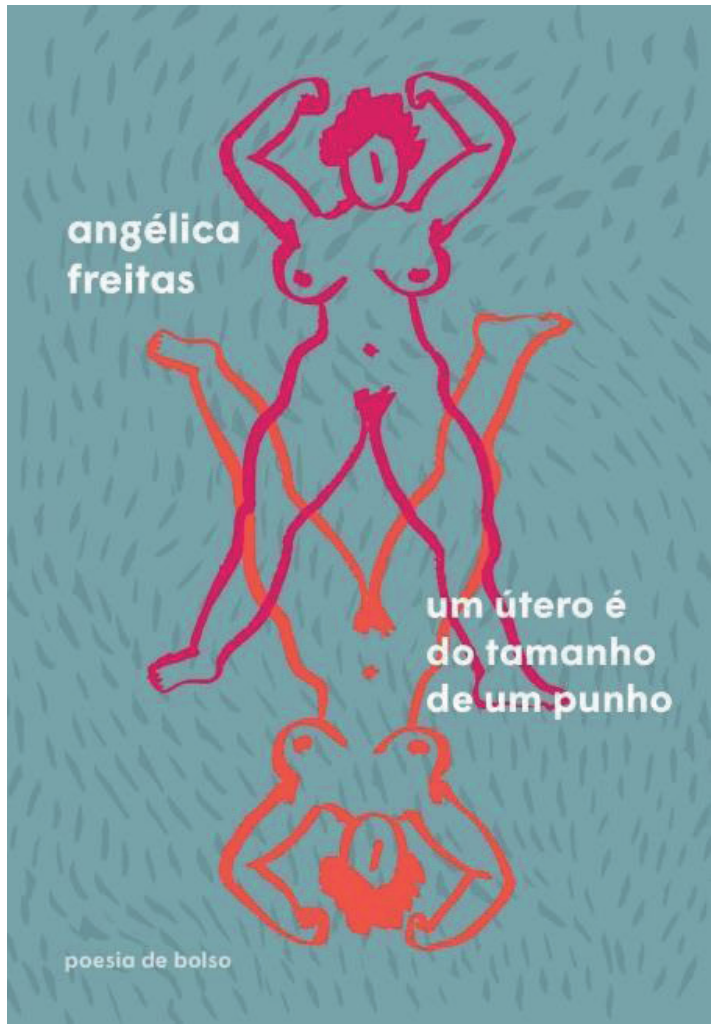

Fonte: Companhia das Letras.

O "revezamento/etapa" (BARTHES, 1990) da leitura da capa, que faz com que a pessoa que leia una a imagem ao título da obra, bem como o fato de ser escrita por uma mulher, caminham rumo à leitura de criaçôes de espaços políticos, de uma certa busca em projetar aquilo que a memória ainda recalca e busca esconder. $\mathrm{O}$ espaço político, caro à poética de Ana Cristina Cesar e Angélica Freitas, já é construído daí. Questionamse figuras como "força", "feminilidade, "mulher", "corpo", "útero" e "punho", na qual a ilusâo do real e o título da obra atuam de modo irônico e provocativo para o leitor. Por conseguinte, a escrita do livro foi marcada por uma experiência particular vivenciada por Angélica durante uma viagem ao México:

Eu tava viajando. E acompanhei essa minha amiga, fui com ela num posto de saúde na Cidade do México. Lá, apesar de o aborto ser legalizado, tem grupos religiosos que sâo contra o aborto e fazem plantấo na frente do centro de saúde. Usam megafones, levam maquetes dos fetos em diferentes estágios de formaçăo. Independentemente de achar uma coisa ou outra, da minha opiniáo sobre o aborto, a coisa era muito chocante, meio louca, năo dava pra acreditar muito bem que aquilo ali tava acontecendo. E como eu tava lá dentro e tinha que sair às vezes pra comer, elas me atacavam, náo me deixavam em paz. "Convence a tua amiga a năo abortar, ainda dá tempo. Porque Jesus te ama". E a gente teve que ir dois dias nesse centro de saúde e foi muito trash. A situaçăo é horrível, sabe, ninguém vai cantando fazer um aborto. Tu vai porque tu realmente năo pode ter o filho, năo tem condiçáo de criar. E a partir dessa experiência, dessa interferência dessas mulheres - eram todas mulheres, năo tinha homens... E a partir dessa interferência eu fiquei pensando, "pô, mas quem elas acham que săo pra se meter na vida dos outros?" Mas aí, extrapolando, eu me pergunto assim, "quem é que manda no corpo da mulher afinal?" (FREITAS, 2012, s/p) 
Năo só a cena descrita, mas o próprio título do livro já propóe uma reflexăo sobre as dominaçôes impostas para o sexo feminino, sintetizadas na pergunta de Angélica "quem é que manda no corpo da mulher afinal?". Ademais, ao assemelhar o órgăo feminino à măo fechada, gestual para um soco (por si só, sinal de agressăo) a obra de antemăo cede um espaço para discussōes que visam problematizar a indissociável relaçăo entre violência e o corpo da mulher na sociedade brasileira. Há inclusive um longo poema que leva o título do livro, cuja passagem selecionada transpóe para o plano da literatura o que havia acontecido durante a estadia da autora no México:

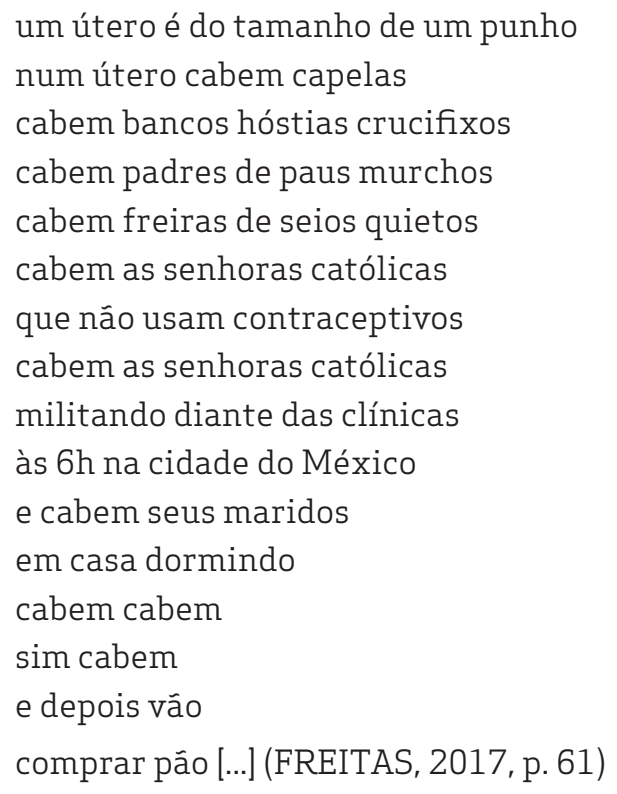

No plano da sonoridade, a aproximaçăo entre útero e punho é mais de ordem semântica do que fonológica, fazendo com que haja uma similitude entre seus significados. Percebe-se na atitude das "/senhoras católicas/", "/militando diante de clínicas/", uma obrigaçáo compulsória ao órgâo feminino: o da reproduçâo. Tal imposiçăo é violenta "/do tamanho de um punho/" e ignora a próprio discurso falido pela qual se assentam, isto é, sendo católicas e aparentemente condizentes com os dogmas católicos, nâo deveriam ser "/senhoras que usam contraceptivos/". Imagens como "/ padres de paus murchos /" e "/freiras de seios quietos/"9 evocam as instâncias que legitimam o abuso contra os corpos femininos: igreja, estado, escola, grupos religiosos, entre outros. O excerto termina com os maridos despreocupados "/em casa dormindo/" e com a atitude igualmente insólita das senhoras "/e depois vâo / comprar pâo/", assinalando uma certa naturalidade para com os dispositivos de controle (FOUCAULT, 2012), tal qual uma atitude corriqueira e banal, que faz lembrar os trechos de "Panis et Circenses", da banda brasileira Os Mutantes: "Mas as pessoas da sala de jantar. Sáo ocupadas em nascer e morrer". A violência parece uma gestualidade naturalizada, por tudo e por todos(as) e que inclusive faz com que as próprias mulheres se voltem como

9 Esses versos fizeram com que Angélica fosse alvo de diversas críticas e que o livro gerasse uma moçăo de repúdio por parte da Assembleia Legislativa de Santa Catarina, em que deputados argumentaram sobre a retirada do texto da lista de leituras obrigatórias para o Vestibular 2020 da Universidade Federal do Rio Grande do Sul. (Cf.: <https://www.correiosc.com.br/livro-de-poesias-para-o-vestibular-da-ufsc-gerapolemica-na-alesc/>. Acesso em: 24 mar. 2020.) 
inimigas de seu sexo, congruente com o sistema de dominaçăo imposto e a lógica do papel da mulher no mundo.

Essa naturalizaçăo do sexo, a busca pelo eterno feminino que Simone de Beauvoir contestava em 0 segundo sexo (1949), fez com que se criasse uma ficçâo para o corpo da mulher, em que há o possível e o improvável para o feminino, o que se pode e o que nâo se pode fazer. Săo as "ficçōes reguladoras que consolidam e naturalizam regimes de poder convergentes de opressăo masculina e heterossexista" (BUTLER, 2019, p. 70). Tal narrativa ficcional em torno do sexo/gênero é igualmente percebida na seçâo "argentina", de Um útero é do tamanho de um punho:

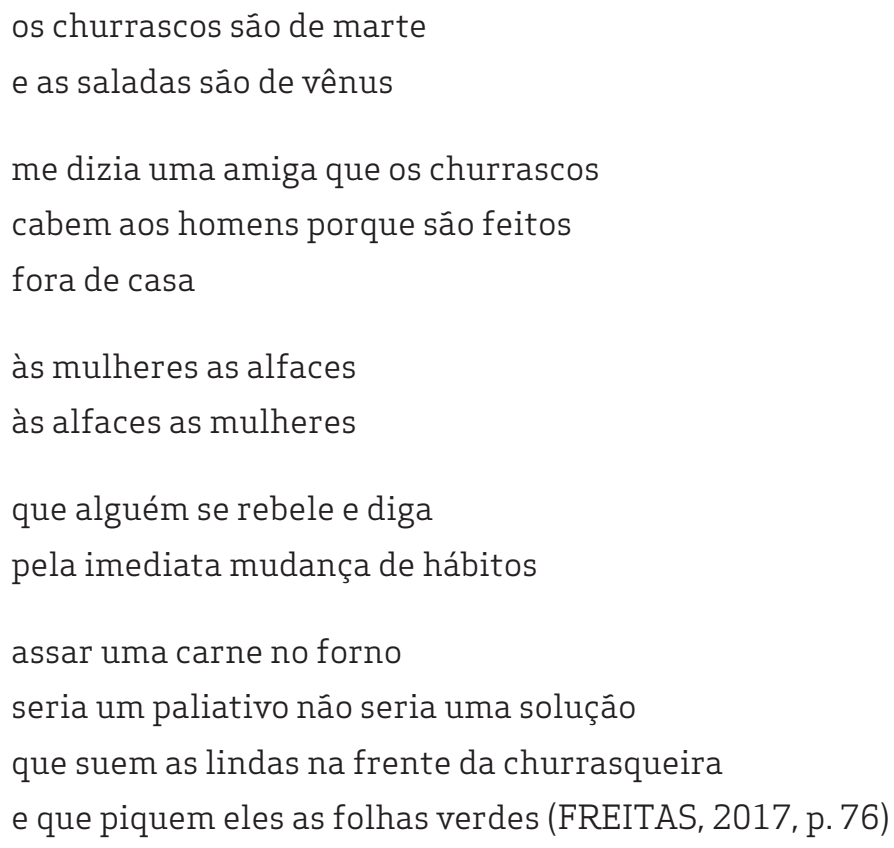

O poema inicia com um irônico intertexto nos dois primeiros versos "os churrascos săo de marte / e as saladas săo de vênus", fazendo referência ao livro Os homens sâo de marte, mulheres sâo de vênus (1992), do escritor norte-americano John Gray. A obra tornou-se um best-seller mundial e uma espécie de guia para os relacionamentos modernos heterossexuais, contudo, năo faz mais do que celebrar as diferenças entre os sexos por critérios de exclusâo e atribuiçóes culturalmente construídas. Os homens marcianos - seriam dotados da racionalidade e aptidâo para as atividades ditas "masculinas", como o trabalho e a conquista do mundo; já as mulheres - venusianas - estariam restritas ao campo dos afazeres domésticos e dotadas de um espírito de sensibilidade e emoçáo, como atribuiçóes essencialmente ligadas ao sexo feminino. Sendo assim, a tônica do livro é a de que um relacionamento entre homem e mulher deve levar em contas as diferenças emocionais inerentes à cada sexo, desconsiderando a existência de masculino(s) e feminino(s), em toda sua acepçâo plural. É a ideia que se segue nos versos seguintes, colocando o churrasco como uma atividade masculina "porque săo feitos /fora de casa" e as hortaliças (mais leves e menos calóricas) enquanto uma condiçăo feminina "às mulheres as alfaces/as mulheres as alfaces".

Contrário às convençôes, o eu lírico opta pela rebeldia "que alguém se rebele e diga /pela imediata mudança de hábitos", em direçăo a uma posiçăo que assuma o devir do sexo enquanto possibilidade e nâo como disciplina. Se os papéis de gênero sâo criados 
"mediante performances sociais" (BUTLER, 2019, p. 244), podemos pensar em novas atribuiçōes/constituiçôes. Ludicamente, o eu lírico apresenta algumas soluçôes "que suem as lindas na frente da churrasqueira/e que piquem eles as folhas verdes", embora reconhecendo que ainda que constituam mudanças significativas, săo mais um paliativo do que uma soluçâo, "seria um paliativo/năo seria uma soluçăo". Uma transformaçâo social só é possível na medida em que sejam modificados os códigos estéticos, políticos, econômicos e semióticos vigentes, entre tantos outros. Por esse viés e em se tratando de linguagem, as construçôes literárias de Ana Cristina Cesar e Angélica Freitas questionam noçōes históricas e colocam o corpo da mulher na "discussâo do dia".

\section{A VOLTA DO CORPO E A PRESENÇA FEMININA NA LITERATURA}

Ao promover uma volta do corpo, a poesia de Ana Cristina Cesar e Angélica Freitas serve de parâmetro para questionarmos algumas concepçóes historicamente construídas. Nessa direçăo, se a gênese da modernidade é marcada pelo cogito cartesiano "penso, logo existo", a máxima de Descartes corresponde a uma consideraçăo de outrora, a do pensamento enquanto única força de realizaçăo e existência, e que há muito foi ultrapassada. O corpo, ente esquecido e excluído no método do filósofo, retorna na literatura contemporânea, que promove constantemente o descentramento da lógica cartesiana, a julgar pela aproximaçăo com as experiências corpóreas e o retorno do estatuto do sujeito à cena de suas discussóes e representaçóes. A respeito de tais proposiçōes, podemos pensar nas consideraçôes de Freud no clássico 0 mal-estar na civilizaçāo, publicado em 1930, em que o psicanalista diagnosticava nosso corpo como uma das causas do sofrimento humano na modernidade:

Logo, nossas possibilidades de felicidade sâo restringidas por nossa constituiçáo. É bem menos difícil experimentar a infelicidade. $O$ sofrer nos ameaça a partir de três lados: do próprio corpo, que, fadado ao declínio e à dissoluçăo, năo pode sequer dispensar a dor e o medo, como sinais de advertência; [...] (FREUD, 2011, p. 20, grifo nosso)

É o caso da literatura das autoras que escolhemos, nitidamente marcada por uma volta do corpo enquanto possibilidade de escrita, seja enquanto objeto de descoberta e reiteraçâo do eu, no caso de Ana Cristina Cesar, ou enquanto objeto de denúncia e problematizaçâo mais incisiva de uma construçâo histórica, características perceptíveis da poética de Angélica Freitas em Um útero é do tamanho de um punho. É importante notar que a abertura de temas iniciada por Ana Cristina Cesar nas décadas de 70 e 80 e essa nova possibilidade de falar do corpo feminino com naturalidade ainda năo é uma realidade do século XXI, o que faz com que Angélica Freitas questione os estereótipos ainda presentes nas práticas e discursos cotidianos que se impóem à mulher, no passado ou no presente.

Além disso, é preciso considerar que a retomada de uma literatura de autoria feminina, sem precisar que a encaixemos enquanto uma "literatura feminista", age como questionamento náo somente à ideia de naçăo brasileira, mas também de literatura brasileira. É forçoso desconsiderar que uma tessitura poética oriunda de mulheres nâo existisse desde a formaçấo de nossa naçăo, o que năo é percebido ou discutido, no âmbito acadêmico ou fora delas, por um movimento consciente e inconsciente de exclusâo 
dessas vozes. Em "Feminismo: uma história a ser contada", Constância Lima Duarte adverte que, no Brasil, se "a história do feminismo é pouco conhecida, deve-se também ao fato de ser pouco contada" (DUARTE, 2019, p. 26). Nesse ínterim, Duarte (2019) recupera escritoras como Nísia Floresta Brasileira Augusta, Beatriz Francisca de Assis Brandăo, Clarinda da Costa Siqueira, Delfina Benigna da Cunha, Ana Eurídice Eufrosina de Barandas e Júlia Albuquerque Sandy Aguiar, comprovando a existência de mulheres que escreviam já na primeira metade do século XIX e que aproveitaram o momento institucional de abertura das primeiras escolas públicas femininas autorizadas pela legislaçăo de 1827.

Ao aproximar-nos de tais escritoras e perceber "na literatura, mulheres que reescrevem a naçăo", para lembrarmos outro texto importante para o resgate histórico feminino, de Rita Terezinha Schmidt, percebemos que a construçáo do Brasil enquanto um Estado Moderno lançou máo de uma política de silenciamento, na literatura e em outros campos, dos quais "constituiu-se um domínio masculino, de forma explícita e excludente" (SCHMIDT, 2019, p. 65). A retomada de textos escritos por mulheres nâo só reescreve a naçāo, mas "levantam interrogaçôes acerca de premissas críticas e formaçôes canônicas, bem como tensionam as representaçôes dominantes calcadas no discurso assimilacionista de um sujeito nacional náo marcado pela diferença" (SCHMIDT, 2019, p. 66). Um projeto novo de naçăo/literatura, em que as futuras geraçôes possam percebem a existência de uma presença feminina na literatura desde os primórdios de nossa organizaçâo social.

\section{CONSIDERAÇÕES FINAIS}

Ao chegarmos em nossas consideraçōes finais, que embora prenunciam um argumento final abrem-se mais para a inconclusăo, talvez seja o momento de questionarmos se o "anjo do lar" foi devidamente morto, se o corpo feminino pode ser em toda sua potencialidade, se nâo há novas indagaçôes que possam ser feitas e verificadas. Na verdade, ao levarmos em conta que no Brasil contemporâneo temas como a legalizaçăo do aborto e a liberdade para o sexo feminino ainda sâo tabus, sobretudo por pressóes religiosas e políticas, que a violência contra o corpo das mulheres presentifica-se enquanto uma realidade maciça e cotidiana, e há inúmeros estereótipos atrelados à ideia de "mulher", as discussōes de outrora ainda sâo as de hoje. Ainda somos os mesmos e vivemos da mesma forma, em diversas circunstâncias.

De fato, certas ditaduras nunca morrem, como as anunciadas nesse texto, e retornam de tempos em tempos, com outras expressôes, máscaras e trejeitos. Pensando nisso, concluímos (esta sim uma conclusâo possível) que a intimidade e subjetividades alcançadas por Ana Cristina Cesar, inserindo-as no contexto de uma mulher e a descoberta do seu corpo, ainda năo săo uma totalidade contemporânea. Essa constataçăo é sentida quase três décadas mais tarde na poesia de Angélica Freitas, consciente de que há um longo caminho que se possa percorrer na conquista de uma liberdade política do ser.

Todavia, ao propormos uma aproximaçâo entre a poética de Ana Cristina Cesar e a de Angélica Freitas, pensamos que nâo somente no plano interdiscursivo é que ambas as escritoras possuem traços de semelhança, mas também no plano da expressâo, a exemplo da opçáo por versos livres, um poema que se mescle com a prosa e uma escrita 
lado a lado com o imagético cotidiano, valendo-se de imagens do senso comum e aparentemente banais para a construçăo de um universo ficcional em que muito se possa dizer e sentir. Sem dúvida, Ana C. e Angélica Freitas podem ser vistas como nomes importantes para o fomento de escritas de autoria feminina, da qual Ana Cristina Cesar abre o terreno com a geraçăo de 60 e 70 e Angélica Freitas dá seguimento nas primeiras décadas do século XXI. Muitas outras escritoras, decerto, poderiam ser citadas, confirmando năo só que uma dicçăo feminina literária possui uma presença potente, mas que é tarefa da crítica contemporânea revisitar essas vozes, a fim de uma formaçâo e ideia de literatura da inclusăo e náo da exclusăo.

Por fim, pensar a partir de uma literatura feita por mulheres, antes do que somente marcar uma presença, é compartilhar as experiências e dar voz a um discurso que, ainda que negado e soterrado pela história, tem todo o direito de se pronunciar. Trata-se de compreender a potencialidade da tônica feminina e suas reivindicaçôes a partir do texto literário, e, acima de tudo, ouvir esses corpos políticos que foram excluídos. 


\section{REFERÊNCIAS}

BARTHES, Roland. 0 óbvio e o obtuso: ensaios críticos III. Trad. Léa Novaes. Rio de Janeiro: Nova Fronteira, 1990.

BEAUVOIR, Simone de. 0 segundo sexo. A experiência vivida. 2. ed. Trad. Sérgio Milliet. Sáo Paulo: Difusāo Europeia do livro, 1980.

BOSI, Viviana. à mercê do impossível. In: CESAR, Ana Cristina. Poética. Săo Paulo: Companhia das letras, 2013, pp. 425-431.

BUTLER, Judith. Problemas de gênero: feminismo e subversăo da identidade. 18. ed. Trad. Renato Aguiar. Rio de Janeiro: Civilizaçâo Brasileira, 2019.

CANDIDO, Antonio. O direito à literatura. In: Vários escritos. 5. ed. Rio de Janeiro: Ouro sobre azul, 2013, pp.171-193.

CESAR, Ana Cristina. Poética. Săo Paulo: Companhia das letras, 2013.

DUARTE, Constância Lima. Feminismo: uma história a ser contada. In: HOLLANDA, Heloisa Buarque de. (org.). Pensamento feminista brasileiro: formaçâo e contexto. Rio de Janeiro: Bazar do tempo: 2019, pp. 25-47.

FOUCAULT, Michel. Microfísica do poder. Rio de Janeiro: Graal, 2012.

FREITAS, Angélica. Rilke shake. Săo Paulo: Cosac Naify, 2007.

FREITAS, Angélica. Um útero é do tamanho de um punho. Sâo Paulo: Companhia das letras, 2017.

FREITAS, Angélica. “O ano de Angélica Freitas" [entrevista]. In: Segunda linha, 2012. Entrevista concedida a Roberto Soares Neves. Disponível em: <https://segundalinha. wordpress.com/2013/01/20/o-ano-de-angelica-freitas/>. Acesso em: 24 mar. 2020.

FREITAS, Angélica. Poema inédito de Angélica Freitas em homenagem a Ana Cristina Cesar [reportagem], 2016. Disponível em: <https://www1.folha.uol.com.br/serafina/2016/07/1785342-leia-poema-inedito-de-angelica-freitas-em-homenagem-a-ana-cristina-cesar.shtml>. Acesso em: 24 mar. 2020.

FREUD, Sigmund. 0 mal-estar na civilizaçăo. Trad. Paulo César de Souza. Săo Paulo: Penguin Classics; Companhia das Letras, 2011.

HOLLANDA, Heloisa Buarque de. (org.). 26 poetas hoje. 4. ed. Rio de Janeiro: Aeroplano, 2001a.

HOLLANDA, Heloisa Buarque de. (org.). Esses poetas: uma antologia dos anos 90. 2. ed. Rio de Janeiro: Aeroplano, 2001b.

HOLLANDA, Heloisa Buarque de. Ana Cristina Cesar: cristais, heavy metal e tafetá. In: CESAR, Ana Cristina. Poética. Săo Paulo: Companhia das letras, 2013a, pp. 450-451.

HOLLANDA, Heloisa Buarque de. A imaginaçăo feminina no poder. In: CESAR, Ana Cristina. Poética. Săo Paulo: Companhia das letras, 2013b, pp. 441-445.

KLEIN, Julia. Na poesia. In: HOLLANDA, Heloisa Buarque de. (org.). Explosáo feminista: arte, cultura, política e universidade. 2. ed. Sâo Paulo: Companhia das Letras, 2018, pp. 105-137. 
SAUSSURE, Ferdinand. Curso de Linguística Geral. Săo Paulo: Cultrix, 2012.

SCHMIDT, Rita Terezinha. Na literatura, mulheres que reescrevem a naçăo. In: HOLLANDA, Heloisa Buarque de. (org.). Pensamento feminista brasileiro: formaçăo e contexto. Rio de Janeiro: Bazar do tempo: 2019, pp. 65-79.

WOOLF, Virginia. Profissóes para mulheres e outros artigos feministas. Trad. Denise Bottmann. Porto Alegre: RS: L\&PM, 2013.

VEJA. "Marcela Temer: bela, recatada e do lar" [reportagem]. Disponível em: https://veja. abril.com.br/brasil/marcela-temer-bela-recatada-e-do-lar/ Acesso em: 24 mar. 2020.

Recebido em05/05/2020

Aceito em 03/06/2020 